\title{
Mass-Mediated Protest Music and Mobilization: Synthesizing the Civil Sphere's EMM-Framing Theory
}

\author{
Jeneve Brooks*
}

\begin{abstract}
Previous scholarship on protest music mostly focuses on its furthering activists' mobilization and does not emphasize its effects on the public. There is also scant attention paid to its impact on people's emotions, moral values, and memories. I propose the synthesized Civil Sphere's EMM-Framing Theory (where EMM stands for Emotive, Moral, and Mnemonic) that focuses on mass-mediated protest music's effects on the public, using research on anti-war music as a case study. Blending cultural sociology, social movements, political psychology, and contemporary ethics' literatures, this theory highlights how protest music may sway public opinion and voting in support of movement goals, besides encouraging direct activism. Although applicable to other discourses representing social changeoriented mass-mediated popular culture, this theory is especially useful for protest music, because it emphasizes emotion, moral messaging, and memory, corroborating research on music effects. The theory also addresses ideology, collective identity, political socialization, and celebrity thought leaders. [Article copies available for a fee from The Transformative Studies Institute. E-mail address: journal@transformativestudies.org

Website: http://www.transformativestudies.org (C2015 by The Transformative Studies Institute. All rights reserved.]
\end{abstract}

KEYWORDS: Protest Music, Social Movements, Emotion, Framing, Moral, Memories, Public.

\footnotetext{
* Jeneve Brooks, Ph.D., is an Assistant Professor of Sociology at Troy University in Dothan, AL. She researches protest music, mass media/popular culture, social movements, political psychology, emotions, race relations, and much more. Jeneve contributed to Music Sociology: An Introduction to the Role of Music in Social Life (Horsfall, Meij, and Probstfield 2013) and has written journal articles for Music and Arts in Action and Race, Gender, and Class. Jeneve is the main organizer for the regional Wiregrass Blues Fest and is also involved in a variety of progressive movements ranging from anti-war mobilization to prison reform. Address correspondence to: Jeneve Brooks, Troy University, 501 University Dr., 401-D Adams, Dothan, Alabama 36301; e-mail: jrbrooks@troy.edu.
} 